\title{
Sistem Pendukung Keputusan Rekomendasi Pemilihan Bank Sebagai tempat Menabung di Kota Ternate Menggunakan Metode MOORA
}

\author{
Soraya Bahrun ${ }^{1}$, Hairil Kurniadi Sirajuddin ${ }^{2}$, Syarifuddin N. Kapita ${ }^{3}$ \\ Fakultas Teknik, Program Studi Teknik Informatika, Universitas Khairun \\ E-mail: Sorayabahrun014@gmail.com
}

\begin{abstract}
Abstrak
Banyak bank di Indonesia baik pemerintah atau swasta yang memberikan banyak penawaran dan keunggulan yang berbeda-beda kepada nasabah. Hal ini yang membuat masyarakat umum bimbang dalam menentukan tempat untuk menabung. Penelitian ini dilakukan terhadap 5 bank yang ada di Kota Ternate. Keputusan yang diberikan oleh metode Moora adalah hasil perengkingan setiap alternatif berdasarkan kriteria penilaian dengan preferensi dan bobot kriteria yang seimbang sehingga menghasilkan keputusan yang lebih objektif.Penambahan bobot kriteria untuk setiap alternatif dapat mempengaruhi penilaian dan hasil perhitungan metode Moora. Hasil dari implementasi yang sesuai dengan data dari bank terkait belum sesuai dengan perancangan karena nilai bobot kriteria yang tidak seimbang dapat mempengaruhi hasil akhir.Maka dari itu dilakukan pengujian metode untuk mendapatkan hasil perengkingan yang sesuai dengan kebutuhan calon nasabah.Sehingga peneliti melakukan pengujian metode dengan menggunakan bobot alternatif yang seimbang dan mendapatkan hasil akhir yang sesuai dengan perancangan sistem.Dimana nilai tertinggi dari pengujian metode yaitu Bank Mandiri dengan hasil akhir 6.8 dan Bank BCA mempunyai nilai terendah yaitu 5.35.Pengujian sistem menggunakan white box telah berhasil dilakukan, dimana basispathtesting yang digunakan untuk melakukanpengujianjalur independentterlewatisemua. Hasil dari implementasi telah sesuai dengan perancangan dan semua modul program telah berfungsi dengan baik.
\end{abstract}

\section{Kata kunci: Sistem Pendukung Keputusan, Pemilihan Bank, Tempat Menabung, moora.}

\begin{abstract}
Many banks in Indonesia, both public and private, provide many different offers and advantages to customers. This makes the general public hesitant in determining where to save. This research was conducted on five banks in Ternate City. The decision given by the Moora method is the result of ranking each alternative based on the assessment criteria with balanced preferences and criteria weights to produce a more objective decision. The addition of standards weights for each option can affect the assessment and calculation results of the Moora method. The implementation results following the data from the related bank are not following the design because the unbalanced weight value of the criteria can affect the final result. Therefore, testing methods are carried out to obtain ranking results following the needs of prospective customers. So the researchers tested the technique using balanced alternative weights and got the outcome following the system design. The highest value from the testing method is Bank Mandiri, with a final mark of 6.8, and Bank BCA has the lowest score of 5.35. System testing using a white box has been successfully carried out, where all the basic path testing used to perform independent path testing has been passed. The implementation results have been following the design, and all program modules have been functioning correctly.
\end{abstract}

Keywords: Decision Support System, Choosing a Bank, Place to Save, Moora. 


\section{PENDAHULUAN}

Perkembangan teknologi informasi saat ini Sangat membantu sektor bisnis dan industri dalam peningkatan produksi hal ini dikarenakan segala aktivitas bisa dilaksankan dengan efektif dan efesien dengan tingkat akurasi yang tinggi..Perusahaan merasa bahwa teknologi dan informasi dapat dijadikan sebagai strategi dalam menghadapi pesaing bisnisnya.Perbankan adalah salah satu badan usaha di bidang jasa keunagan yang meyediakan berbagai macam pilihan produk dan jenis-jenis produk simpan pinjam yang dapat menarik minat dari masyarakat untuk menabung.. Menabung adalah trend baru masyarakat modern, dimana masyarakat lebih memepercayai pihak Bank dalam menyimpan uang, melakukan inventasi maupun merencanakan masa depan. Ditengah banyaknya bermunculan Perusahaan Perbankan dengan berbagai tawaran produk perbankan, masyarakat sudah pasti menginginkan produk yang berkwalitasdan sesuai dengan tingkat pendapatan. Ditengah banyakanya jenis produk yang ditawarkan menyebabkan calon nasabah bingung dalam menetukan jenis produk perbankan yang akan digunakan untuk menabung. Penelitian ini dilakukan terhadap 5 bank di wilayah Kota Ternate.

Sistem pendukung keputusan dapat memberikan informasi dan membantu menyediakan berbagai alternatif yang dapat membantu proses pengambilan keputusan dengan lebih akurat dan objektif. Beberapa metode SPK yang digunakan dalam proses pengambilan keputusan diantaranya metode Weighted Product, Analytic Hierarchy Process, SAW, Promethee, Topsis, VIKOR dan lain-lain.
Penelitian yang terkait antara lain penelitian mengenai SPKAnalisa rekomendasi bank konvensional dengan promethee untuk pilihan tepat memilih jenisproduk tabungan. Penelitian ini mengusulkan sebuah sistem pendukung keputusan untuk rekomendasi jenis produk bank yang tepat untuk menabung. Metode promethee menghasilkan keputusan dengan melakukan perbandingan antar alternatif berdasarkan fungsi preferensi dan bobot yang berbeda-beda dari setiap kriteria dimana hasil keputusan ditentukan dari hasil pemeringkatan promethee II (net flow).Kriteria yang akan di pakai dalam rekomendasi jeni produk bank adalah suku bunga, banyaknya mesin ATM,besaran setor awal. Biaya adminintrasi dan service. Hasil dari penelitian ini merekomendasikan bahawa Bank Mandiri menjadi pilihan tepat untuk menabung dengan nilai net flow 0,725 .

\section{TINJAUAN PUSTAKA}

\section{Sistem pendukung keputusan}

Sistem pendukung keputusan merupakan suatu pendekatan (metodologi) untuk mendukung pengambilan keputusan.Decision Support System(DSS), menggunakan Computer Based Information System(CIBIS) yang fleksibel, interaktif, dan dapat diadaptasoi, yang dikembangkan untuk untuk mendukung solusi untuk masalah manajemen spesifik yang tidak terstruktur.DSS menggunakan data, memberikan antarmuka pengguna yang mudah, dan dapat menggabungkan pemikiran pengambil keputusan (Turban, 2005).

\section{Bank}

Bank merupakan lembaga keuangan yang memiliki peranan yang sangat penting dimana dalam kegiatannya, bank 
sebagai penghimpun dana nasabah dalam giro, tabungan dan deposito yang dana tersebut disalurkan kembali kepada masyarakat dalam bentuk kreepublik Indonesia No.10 tahun 1998 tentang perbankan, bank merupakan badan usaha yang mengumpulkan dana masyarakat dengan bentuk produk simpanan kemudian disalurkan kembali bentuk pinjaman utnuk mebantu keberlangsungan bisnis masyarakat.. Salah satu aktifitas perbankan adalah mengumpukan dana mayarakat atau sering disebut dengan aktivitas funding. Dalam undang-undang perbankan nomor 10 tahun 1998, yang dimaksud dengan tabungan yang simpanan penarikannya hanya dapat dilakukan menurut syarat-syarat yang disepakati (Nugraha, 2015).

\section{MOORA}

Metode

Multi-Objective Optimization by Ratio Analysis (MOORA) adalah metode yang dirancang oleh Brauers dan Zavadkas (2006). Metode MOORA mempunyai tingkat fleksibel dan kemudahan untuk dimengerti dalam memisahkan bagian subjektif dari suatu proses evaluasi kedalam kriteria bobot keputusan dengan beberapa atribut pengambilan keputusan (Mandal, 2012). Metode ini memiliki tingkat selektifitas yang baik karena dapat menentukan tujuan dari kriteria yang bertentangan. Dimana kriteria dapat bernilai menguntungkan (benefit) atau yang tidak menguntungkan (cost).

Berikut ini adalah beberapa rumus yang dapat digunakan pada metode MOORA, yaitu:

Langkah 1: langkah pertama adalah penentuan dan identifikasi atribut evaluasi atau menginput nilai kriteria.
Langkah 2: langkah berikutnya menampilkan semua informasi yang tersedia untuk atribut dalam bentuk matriks keputusan. $X$ merupakan nilai kriteria dari masing-masing kriteria yang direpresentasikan sebagai matriks. Untuk lebih jelasnya dapat diliha pada rumus 2.1 dibawah ini:

$$
x=\left[\begin{array}{cccc}
x_{11} & x_{1 i} & \cdot & x_{1 n} \\
x_{1 j} & x_{i j} & \cdot & x_{j n} \\
\cdot & \cdot & \cdot & \cdot \\
x_{m 1} & x_{m 2} & \cdot & x_{m n}
\end{array}\right]
$$

Keterangan:

$x_{i j}=$ respon alternatif $\mathrm{j}$ pada atribut $\mathrm{i}$

$i=1,2,3, \ldots, n$ adalah nomor urutan atribut atau kriteria

$j=1,2,3, \ldots, m$ adalah nomor urutan alternatif

$\mathrm{x}=$ matrix keputusan

Langkah 3: Brauers menyimpulkan bahwa denominator, pilihan terbaik dari akar kuadrat dari penjumlahan kuadrat dari setiap alternatif per atribut. Rasio ini dapat dinyatakan pada persamaan 2.2 sebagai berikut:

$$
x_{i j}=\frac{x_{i j}}{\sqrt{\left[\sum_{n=1}^{m} x_{i j}^{2}\right]}} .
$$

Keterangan:

$x_{i j}=$ respon alternatifj pada atribut $\mathrm{i}$

$i=1,2,3, \ldots, n$ adalah nomor urutan atribut atau kriteria

$j=1,2,3, \ldots, m$ adalah nomor urutan alternatif

$x_{i j}=$ matrix normalisasi alternatif $\mathrm{j}$ pada kriteria i

Brauers menyimpulkan bahwa untuk denominator, pilihan terbaik dari akar kuadrat dari penjumlahan kuadrat dan dari setiap alternatif per kriteria. Dan selanjutnya mengoptimasi nilai atribut dengan cara nilai normalisasi dikalikan dengan bobot.

Langkah 4: Hasil normalisasi adalah penjumlahan dalam hal pemaksimalan (dari atribut yang menguntungkan/ benefit) dan pengurangan dalam hal peminimalan 
(dari atribut yang tidak menguntungkan/cost). Dinama nilai $g$ adalah nilai kriteria yang akan dimaksimalkan, dan (n-g) adalah nilai dari kriteria yang diminimalkan, sedangkan Yi adalah nilai dari penilaian normalisasi alternatif i terhadap semua atribut. memesan untuk memberikan lebih penting atribut, tersebut dilakukan dengan bobot yang sesuai (signifikan koefesien). Ketika bobot kriteria ini dipertimbangkan maka persamaan Yi adalah sebagai berikut:

$$
y_{i}=\sum_{j=1}^{g} w_{j} x_{i j}-\sum_{j=g+1}^{n} w_{j} x_{i j} \cdot(2.3) .
$$

Keterangan:

$g=1,2,3, \ldots, n$ adalah jumlah attribut yang akan dimaksimalkan

$j=g+1, g+2, g+3, \ldots, n \quad$ jumlah attribut atau kriteria yang akan diminimalkan

$W_{j}=$ adalah bobot atribut $\mathrm{j}$

$Y_{i}=$ nilai penilaian yang telah dinormalisasi dari alternatif 1 terhadap semua attribut.

Langkah 5: Nilai $Y_{i}$ menjadi nilai Positif maupun nilai negatif tergantung dari jumlah maksimal (kriteria yang menguntungkan) dan jumlah minimal (kriteria yang tidak menguntungkan) dalam sebuah matriks keputusan. Urutan peringkat dan $Y_{i}$ menujukan pilihan terakhir Alternatif terbaik memiliki nilai $Y_{i}$ tertinggi, sedangkan alternatif terburuk memiliki nilai yang terendah.

\section{Web}

Web merupakan terobosan baru sebagai teknologi sistem informasi yang menghubungkan data dari berbagai sumber dan layanan di Internet. Web sangat populer di kalangan pengguna Internet karena nyaman bagi pengguna Internet untuk mencari, menjelajahi, dan mencari informasi. (Sutopo, 2016).
HyperText Markup Language (HTML)

HTML adalah seperangkat simbol atau tag yang ditulis ke file yang digunakan untuk menampilkan halaman di browser web. Tag HTML selalu dimulai dengan $\mathrm{x}$ dan diakhiri dengan $\mathrm{x}$ Tag HTML seperti b, i, u, dll. (Lumentra, 2018). HTML adalah bahasa yang dikenali oleh browser web untuk menampilkan informasi seperti teks, gambar, suara, animasi, dan bahkan video. (Ardhana, 2012).

\section{Hypertext Preprocessor (PHP)}

Hypertext Preprocessor (PHP untuk jangka pendek) adalah bahasa pemrograman open source yang sangat cocok atau didedikasikan untuk pengembangan web dan dapat disematkan dalam disertasi HTML. Bahasa PHP mudah dipelajari, karena memungkinkan Anda untuk menulis beberapa bahasa pemrograman seperti C, Java, dan Perl. PHP adalah bahasa skrip sisi server di mana pemrosesan data dilakukan di sisi server. Sederhananya, server menerjemahkan skrip program dan hasilnya dikirim ke klien yang meminta. Pengertian lain dari PHP adalah singkatan dari hypertext preprocessor. Ini adalah bahasa pemrograman berbasis kode yang digunakan oleh untuk memproses data dan mengirimkannya kembali ke browser web dalam kode HTML.

Jika file tidak berisi skrip PHP, permintaan pengguna akan ditampilkan langsung di browser, tetapi jika file berisi skrip PHP, proses akan mengubah skrip PHP dan modul PHP sebagai mesin untuk memproses skrip. ke. Dapat dikonversi ke kode HTML dan 
ditampilkan di browser user (Firman, 2016).

\section{Cascading Style Sheet (CSS)}

Cascading Style Sheet (CSS) adalah stylesheet language yang digunakan untuk mendeskripsikan penyajian dari dokumen yang dibuat dalam mark up language. CSS merupakan sebuah dokumen yang berguna untuk pengaturan pada komponen halaman web, inti dari dokumen ini adalah memformat halaman web standar menjadi bentuk web yang memiliki kualitas yang lebih indah dan menarik (Binarso, 2012).

\section{Java SCRIPT}

Java Script adalah bahasa scripting kecil, ringan, berorientasi objek yang ditempelkan pada kode HTML dan di proses di sisi client. Java Script digunakan dalam pembuatan website agar lebih interaktif dengan memberikan kemampuan tambahan terhadap HTML melalui eksekusi perintah di sisi browser. Java Script dapat bereaksi terhadap pesanan klien dengan cepat dan membuat halaman situs menjadi responsif. Java Script memiliki struktur sederhana, kodenya dapat disisipkan pada dokumen HTML atau berdiri sebagai satu kesatuan aplikasi(Firman, 2016).

\section{Basis Data}

Basis Data adalah sebuah basis data yang mengandung satu atau jumlah tabel. Tabel terdiri atas sejumlah baris dan setiap baris mengandung satu atau sejumlah tabel. Tabel terdiri atas sejumlah baris dan setiap baris mengandung satu atau sejumlah tabel". Basis data adalah database server open source yang cukup popul ar.
Keuntungan lainnya, membuat program berbasis informasi ini digunakan secara luas oleh para ahli untuk membuat suatu Project. Adanya fasilitas API (Application Programming Interface) yang dimiliki oleh MySQL, mengizinkan aplikasi komputer yang berbeda yang ditulis dalam dialek pemrograman yang berbeda untuk sampai ke basis informasi MySQL. Tipe data $M y S Q L$, "Tipe data $M y S Q L$ adalah data yang terdapat dalam sebuah tabel berupa field-field yang berisi nilai dari data tersebut. Nilai data dalam field memiliki tipe sendiri-sendiri” (Firman, 2016).

\section{MySQL}

MySQL adalah program server basis informasi yang dapat memperoleh dan mengirim informasi dengan cepat, multi user serta menggunakan peintah dasar Structured Query Language (SQL). MySQL adalah dua jenis izin, yaitu Free Software dan Shareware. MySQL yang biasa kita gunakan adalah MySQL Free Software yang berada dibawah Lisensi GNU/GPL (General Public License). MySQL adalah server kumpulan data gratis, yang menyiratkan bahwa kami diizinkan untuk melibatkan basis informasi ini untuk tujuan individu atau bisnis tanpa membeli atau membayar izin. Selain server basis data, MySQL juga merupakan program yang dapat mengakses kumpulan data MySQL yang berfungsi sebagai server, dan itu berarti bahwa program kami berfungsi sebagai pelanggan. Jadi MySQL adalah sebuah database yang dapat digunakan sebagai Client maupun server. Database MySQL merupakan suatu perangkat lunak yang berbentuk database relasional atau disebut Relational Database Management System (RDBMS) yang menggunakan suatu bahasa 
permintaan yang bernama Structured Query Language. SQL atau juga sering disebut sebagai query merupakan suatu bahasa (language) yang digunakan untuk mengakses database (Saputro, 2012).

\section{XАMPP}

XAMPP adalah sebuah software web server apache yang didalamnya sudah tersedia databaseserverMySQL dan dapat mendukung pemrograman PHP.XAMPP merupakan software yang mudah digunakan, gratis dan mendukung instalasi di Linux dan Windows. Keuntungan lainnya adalah cuma menginstal satu kali sudah tersedia Apache, Web Server, MySQL Database Server, PHP Support (PHP 4 dan PHP 5) dan beberapa module lainnya (Febriyanti, 2012).

\section{Pengujian Software White-Box}

Pengujian pemrograman sangat penting untuk menjamin bahwa pemrograman aplikasi yang telah/sedang dibuat dapat berjalan dengan kegunaan yang normal. Pengembangan atau penganalisis pemrograman harus mengadakan Sesi khusus untuk menguji program yang telah dibuat sehingga kesalahan atau kekurangan dapat dikenali dari awal dan direvisi dengan cepat. Pengujian atau testing sendiri merupakan elemen kritis dari jaminan kualitas perangkat lunak dan merupakan bagian yang tidak terpisah dari siklus hidup pengembangan software seperti halnya analisis, desain dan pengkodean (Shi, 2010).

\section{METODE PENELITIAN}

\section{Metode Pengembangan Sistem}

Metode pengembangan sistem yang digunakan dalam penelitian ini adalah model Waterfall. Langkah-langkahnya adalah sebagai berikut:

a. Requirements

Pada tahap ini akan dilakukan menganalisis bagaimana Sistem Pendukung Keputusan Pemilihan bank sebagai tempat menabung di Kota Ternate dengan menggunakan metode Moora. Dari tahap analisis atau requirements ini juga akan memenuhi kebutuhan user dilakukan pengambilan data dengan teknik Wawancara dan Studi Pustaka.

1. Wawancara

Wawancara (Interview), dengan cara tanya jawab seputar pelayanan dan pemilihan bank sebagai tempat menabung serta permasalahan yang dihadapi saat ini. Setelah dilakukan wawancara dapat dikumpulkan variabel/kriteria yang digunakan dalam pembuatan sistempendukung keputusanPemilihan bank sebagai tempat menabung di Kota Ternate dengan menggunakan metode Moora.

b. Studi Pustaka

Pada Pustaka dimana peneliti mengambil buku-buku maupun jurnal yang terkait dengan Penelitian. Seperti halnya tentang perancangan Sistem Informasi, buku yang terkait dengan dengan Pemrograman Web, buku tentang Basis Data, dan juga buku yang berkaitan dengan waterfall.

\section{c. Design}

Desain Sistem, pada tahapan ini dilakukan perancangan dari Sistem Pendukung Keputusan pemilihan jenis tabungan yang akan dibuat terhadap permasalahan yang ada, dengan menggunakan Unified Modeling Language (UML), flowchart untuk menggambarkan bagan alir sistem yang berjalan saat ini dan sistem yang diusulkandan perancangan database dengan menggunakan Entity 
Relationship Diagram (ERD) dan perancangan antar muka dengan menggunakan microsoft visio.

\section{d. Coding}

Penulisan Kode Program, padatahap ini merupakan penerapan dari Desain Sistem yang direncanakan oleh peneliti dengan memanfaatkan php untuk bahasa pemrograman dan MySQL untuk pengkodean basis datanya. Tahapan ini merupakan tahapan secara nyata dalam mengerjakan suatu sistem. Dalam artian penggunaan komputer akan dimaksimalkan. Hingga menghasilkan sebuah program, seperti website.

e. Testing

Pengujian program, setelah tahap penulisan kode program maka akan dilakukan testing/pengujian dengan tujuan untuk menemukan kesalahan atau bugs dari sistem yang kemudian nantinya dilakukan pengkajian ulang dan perbaikan. Masukan-masukan dari pihak bank di Kota Ternate.

\section{f. Maintenance}

Pada tahap ini penulis tidak melakukan pemeliharaan, pengembangan aplikasi hanya sampai pada tahap pengujian.

\section{ANALISIS DAN PERANCANGAN}

Tahap perancangan sistem memiliki tujuan untuk mengubah model informasi yang telah dibuat selama tahapan analisis menjadi model yang sesuai dengan teknologi yang akan dipergunakan untuk implementasi sistem pendukung keputusan rekomendasi pemilihan Bank sebagai tempat menabung dikota Ternate menggunakan database relasional untuk implementasinya. Perancangan ini menggunakan unified modeling language (UML). Perancangan antar muka dengan menggunakan microsoft visio dan perancangan form inputUsecace diagram admin dan user dapat dilihat pada gambar dibawah ini:

\section{Admin}

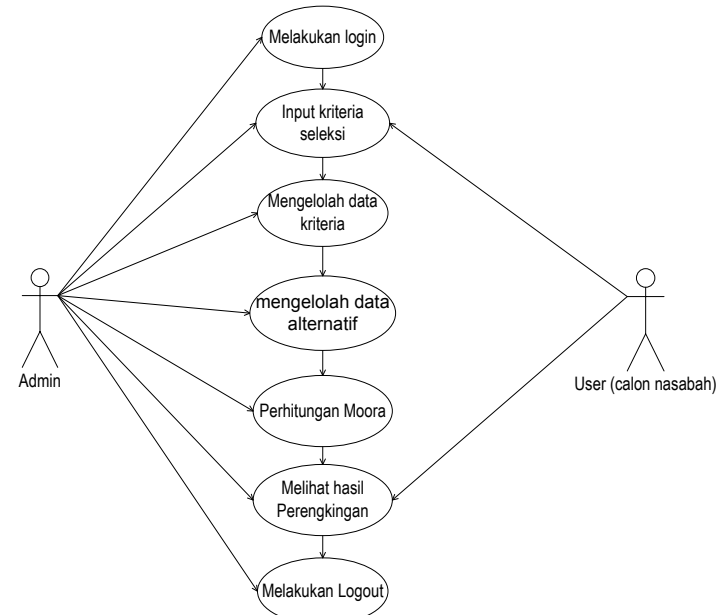

Gambar 1. Usecase Diagram Admin Dan User (Calon Nasabah)

Gambar 1. usecase diagram admin dan user (calon nasabah), mengakses sistem kemudian melakukan login, menginput, mengedit, mengahapus data, mengelola sistem, dan logout. Sedangkan calon nasabah,dapat melakukan simulasi krriteria seleksi dan melihat hasil perengkingan.

\section{Pengumpulan Data}

Dari hasil pengumpulan data yang telah dijelaskan sebelumnya didapatkan bahwa kriteria yang gunakan dalam penelitian ini terdiri dari 5 kriteria. Selanjutnya dilakukan penentuan sub kriteria untuk masing-masing kriteria tersebut. dapat dilihat pada tabel 4.1 yang merupakan tampilan dari data sampel, yang mana data sampel ini akan dihitung menggunakan metode Moora.

Tabel 1 Data Kriteria

\begin{tabular}{|c|c|c|c|c|c|}
\hline \multirow{2}{*}{ Alternatif } & \multicolumn{5}{|c|}{ Kriteria } \\
\cline { 2 - 6 } & C1 & C2 & C3 & C4 & C5 \\
\hline A1 & 3 & 4 & 4 & 5 & 1 \\
\hline A2 & 3 & 4 & 3 & 2 & 5 \\
\hline A3 & 3 & 5 & 3 & 3 & 3 \\
\hline A4 & 5 & 2 & 3 & 3 & 4 \\
\hline A5 & 5 & 2 & 4 & 2 & 4 \\
\hline
\end{tabular}


Dari data diatas akan dihitung menggunakan metode Moora maka rekomendasi yang diperoleh dengan nilai tertinggi dan terbesar ada pada A3, adalah alternatif yang terpilih sebagai alternatif adalah Bank Mandiri. Hasil tersebut didapatkan beberapa rekomendasi untuk pemilihan Bank sebagai tempat menabungbisa dilihat pada tabel 4.2.

Tabel 2 Hasil Perangkingan

\begin{tabular}{|c|c|c|}
\hline Alternatif & Hasil & Rangking \\
\hline A3 (Mandiri) & 6.8 & 1 \\
\hline A2 (BNI) & 6.7 & 2 \\
\hline A4 (BCA) & 6.7 & 3 \\
\hline A1 (BRI) & 5.7 & 4 \\
\hline A5 (BSI) & 5.35 & 5 \\
\hline
\end{tabular}

\section{IMPLEMENTASI DAN PEMBAHASAN}

Pada tahapan implementasi dilakukan dengan pembuatan database, interface dan penulisan kode program.Adapun bahasa pemogramaan adalah PHP.dalam proses pengkodean dibagi menjadi 2 level yaitu: Admin dan calon nasabah. adapun hak akses yang diberikan dari masing-masing level pengguna yaitu sebagai berikut: Administrartor, pada admin ini diberikan full akses. User (calon nasabah), pada bagian user hanya akses, input kriteria seleksi dan melihat hasil rekomendasi.

\section{Tampilan Sistem}

1. Tampilan Login Admin

Untuk tampilan awal dari sistem pendukung keputusan pemilihan bank sebagai tempat menabung diwajibkan terlebih dahululoginuntuk admin.Dapat dilihat pada gambar.

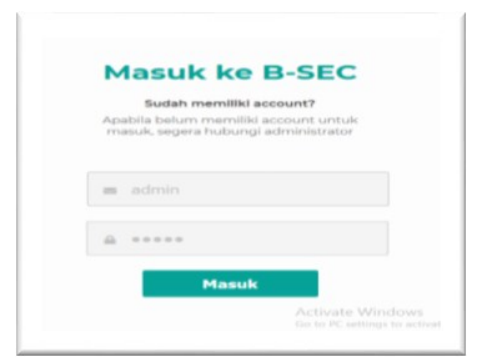

Gambar 2 Tampilan Login Admin

2. Halaman Beranda

Pada halaman utama admin terdapat 4 menu utama yaitu: dashboard, seleksi kriteria, data kriteria, data Alternatifdan user, dan hasil rekomendasi. Menu utama yaitu dashboard admin dapat dilihat pada gambar 3 .

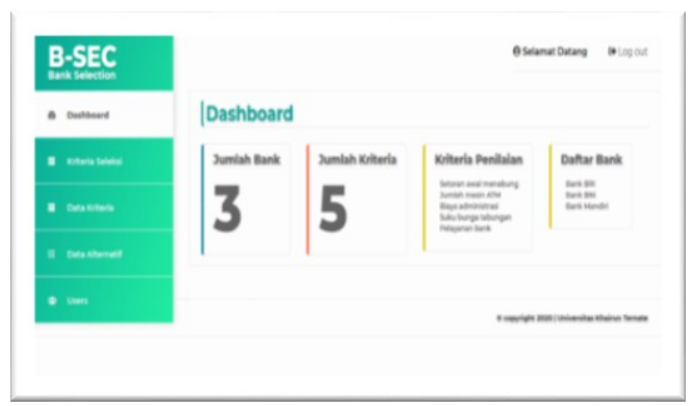

Gambar 3 Tampilan Beranda Admin

3. Tampilan kriteria seleksi

Tampilan kriteria seleksi menampilkan menu kriteria yang akan dipilih oleh calon nasabah hingga hasil rekomendasi bank yang cocok untuk calon nasabah. Untuk melihat hasil rekomendasi diupload dapat dilihat pada gambar 4 .

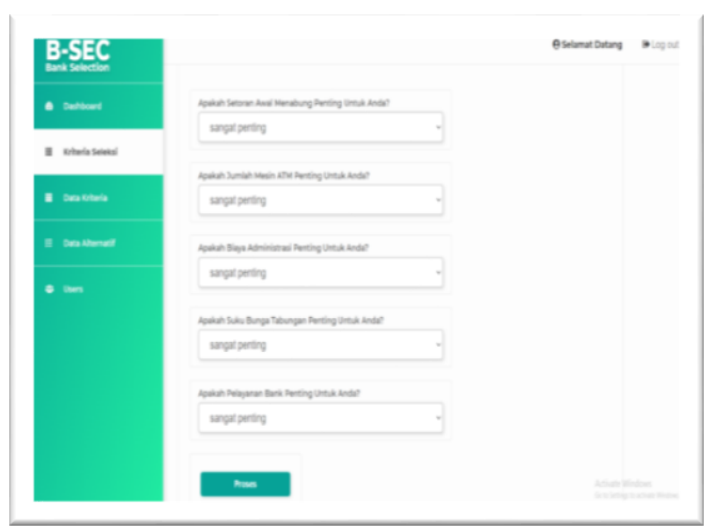

Gambar 4 Tampilan Pilihan Kriteria

\section{Tampilan Data Kriteria}

Tampilan kriteria menampilkan tambah data kriteria, tabel kriteria untuk update kriteria dan menghapus data kriteria gambar 5. 


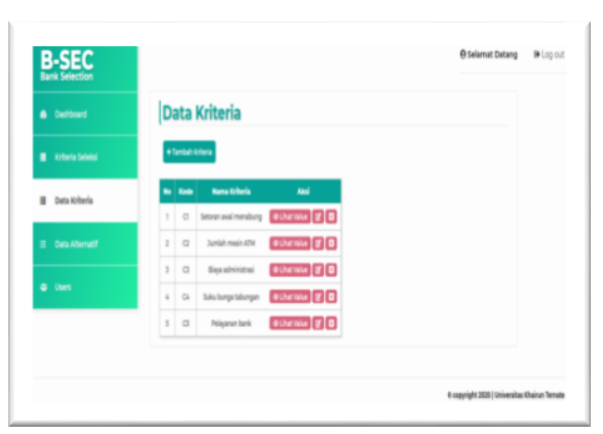

\section{Gambar 5 Tampilan Data Kriteria}

5. Tampilan data alternatif

Tampilan alternatif menampilkan menu dari tambah data alternatif dan menu menghapus data alternatif gambar 4.5.

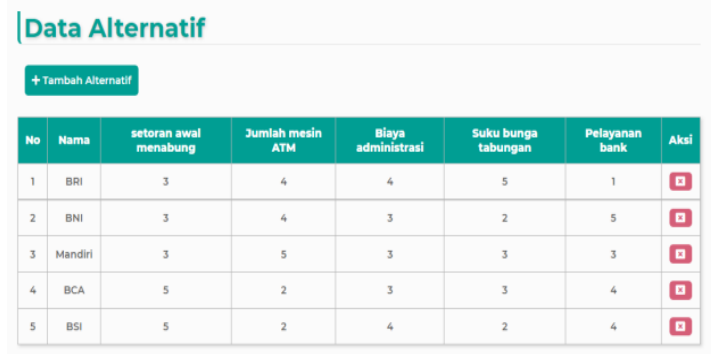

Gambar 6 Tampilan Data Alternatif

\section{KESIMPULAN}

Berdasarkan pembahasan dari babbab sebelumnya, maka dapat ditarik beberapa kesimpulan pada sistem pendukung keputusan rekomendasi pemilihan bank sebagai tempat menabung menggunakan metode Moora sebagai berikut:

1. Keputusan yang diberikan oleh metode Moora adalah hasil perengkingan setiap alternatif berdasarkan kriteria penilaian dengan preferensi dan bobot kriteria yang seimbang sehingga menghasilkan keputusan yang lebih objektif.

2. Penambahan bobot kriteria untuk setiap alternatif dapat mempengaruhi penilaian dan hasil perhitungan metode Moora. Apabila nilai bobot kriteria berbeda jauh atau tidak seimbang, maka hasil rekomendasi akan tetap sama, karena sistem akan memilih bobot kriteria yang paling unggul yang akan menjadi rekomendasi kepada nasabah.

3. Hasil dari implementasi yang sesuai dengan data dari bank terkait belum sesuai dengan perancangan karena nilai bobot kriteria yang tidak seimbang dapat mempengaruhi hasil akhir. Maka dari itu dilakukan pengujian metode untuk mendapatkan hasil perengkingan yang sesuai dengan kebutuhan calon nasabah. Sehingga peneliti melakukan pengujian metode dengan menggunakan bobot alternatif yang seimbang dan mendapatkan hasil akhir yang sesuai dengan perancangan sistem. Sehingga mendapatkan nilai tertinggi dari pengujian metode yaitu Bank Mandiri dengan hasil akhir 6.8 dan Bank BCA mempunyai nilai terendah yaitu 5.35.

4. Perancangan sistem dimulai dengan perancangan tampilan/flowchart, desain interfaces, sampai tahap pengkodean dan pengujian. Pengujian sistem menggunakanwhite box telah berhasil dilakukan, dimana basispathtestingyangdigunakan untuk melakukanpengujianjalur independentterlewati semua. Hasil dari implementasi telah sesuai dengan perancangan dan semua modul program telah berfungsi dengan baik.

\section{DAFTAR PUSTAKA}

Assrani, D., Huda, N., Sidabutar, R., Saputra, I., \& Sulaiman, O. K. (2018). 
Penentuan Penerima Bantuan Siswa Miskin Menerapkan Metode Multi Objective Optimization on The Basis of Ratio Analysis (MOORA), 5(1), 15.

Ardhana, (2012). Perancangan perpustakaan online dengan PHP, mysql, dan CSS. Yogyakarta: Maxikom

Ariyanti, J., \& Purnomo, A. S. (2019). Rekomendasi Pemilihan Produk Tabungan Bank Menggunakan Metode Weighted Product ( WP ), 4(1), 1-9.

Firman, (2016). Bahasa PHP dapat dikatakan menggambarkan beberapa bahasa pemrograman seperti $\mathrm{C}$, Java, dan Perl serta mudah untuk dipelajari.PHP merupakan bahasa scripting server - side.

Imandasari (2018). Sistem pendukung keputusan dalam merekomendasikan unit terbaik di PDAM tirta lihou menggunakan metode promethee. Jurnal teknologi dan sistem komputer, 5 (4), 159-165

Jayanti, E. (2015). Penerapan Metode Simple Additive Weighting Dalam Sistem Pendukung Keputusan Perekrutan Karyawan ( Studi Kasus : Pt. Perkebunan).

Kusuma, Nasution, Safarti, Hondro, \& Buulolo, (2018). Sistem Pendukung Keputusan Pemilihan Siswa/I Teladan Dengan Menggunakan Metode Multi-Objective Optimization on The Basis of Ratio Analisis( MOORA ), 5(2), 114-119.

$\mathrm{N}$ tri, W Afrialita, M Viya, PW Agus. (2018). Analisa Rekomendasi Bank Konvensional Dengan Promethee Sebagai Solusi Cerdas Menabung.

Nasution, (2015). Sistem pendukung keputusan pemilihan Bank diKota Medan dengan metode SMART

Nency Nurjannah, dkk, (2015). Sistem Pendukung Keputusan Pembelian Sepeda Motor Dengan Metode Weighted Product. Program Studi
Ilmu Komputer, FMIPA

Universitas Mulawarman

Nugraha, H., \& Maharani, S. (2015). Sistem Pendukung Keputusan Rekomendasi Pemilihan Bank untuk Pembukaan Rekening bagi Calon Nasabah menggunakan Metode Topsis, 2-5.

Rini, (2010) Entity Relationship Diagram (ERD).

Saputro, H. (2012). Modul Pembelajaran Praktek Basis Data ( MySQL ).

Turban, Aronson, dan Liang. (2005). Decision Support System and Intelligent Systems (Sistem Pendukung Keputusan dan Sistem Cerdas) Jilid I Edisi 7. Yogyakarta: Andi. 